\title{
China and Nuclear Arms Control
}

\section{Possible Implications of China's Involvement in Nuclear Arms Talks}

\author{
Alexander G. Savelyev
}

\author{
Alexander G. Savelyev, Dr. of Political Science \\ Primakov Institute of World Economy and International Relations, Moscow, Russia \\ Center of International Security \\ Chief Research Fellow \\ Scopus Author ID: 57192276256 \\ SPIN RSCI: 6755-7058 \\ E-mail: saveliev@imemo.ru \\ Tel.: +7 (985) 99705 23; +7 (499) 1203568 \\ Address: 23 Profsoyuznaya Str., Moscow 117997, Russia \\ DOI: $10.31278 / 1810-6374-2020-18-3-54-69$
}

\begin{abstract}
Beijing explains its firm unwillingness to join the United States and Russia in nuclear arms control talks by the fact that China's nuclear arsenal is incomparable with respective potentials of the world's two leading nuclear powers. China urges Russia and the U.S. to go ahead with the nuclear disarmament process on a bilateral basis, and promises it will be prepared to consider the possibility of its participation in the negotiations only when its counterparts have downgraded their arsenals approximately to China's level. Washington finds this totally unacceptable and demands that China either join the existing Russian-U.S. strategic New START treaty right away or agree to enter into a trilateral nuclear arms control format. This article studies the prospects of China's involvement in nuclear arms talks and analyzes the true reasons behind Beijing's desire to avoid any nuclear disarmament deals at this point. The working hypothesis of this
\end{abstract}


paper is that China's stance on the above issue is by no means far-fetched or propagandistic, and that it is driven by fundamental political, military and strategic considerations. Disregard for this factor and further forceful efforts to bring China to the negotiating table to discuss nuclear arms control will lead to failure.

Keywords: China, the United States, New START, Russia, nuclear arms control, China's nuclear doctrine, nuclear disarmament, no-first-use principle.

T $\mathrm{n}$ December 2019, the United States officially invited China to enter into a strategic security dialogue. The White House said it hoped Beijing's consent to this proposal might become the first step towards an international agreement encompassing all nuclear weapons of the United States, Russia, and China. As expected, this proposal was rejected. China said its nuclear arsenal was much smaller than those of the United States and Russia, and it would be able to participate in such talks only when their nuclear potentials were brought to parity with its own.

In March 2020, U.S. President Donald Trump once again declared his intention to ask Russia and China to hold such talks with the aim of avoiding a costly arms race (Reuters.com, 2020). The Chinese Foreign Ministry's response followed virtually in no time. Its spokesperson Zhao Lijian said that China had no intention of taking part in the socalled China-U.S.-Russia trilateral arms control negotiations, and that its position on this issue was very clear (ECNC.cn., 2020). He called upon the United States to extend the New START and to go ahead with the policy of U.S-Russian nuclear arms reduction, thus creating prerequisites for other countries to join the nuclear disarmament process. There is nothing new about China's stance. A year earlier Chinese Foreign Ministry spokesperson Geng Shuang, while speaking at a news conference in May 2019, made a similar statement. China refused to participate in a trilateral arms control agreement (Fmprc.gov.2019).

It is noteworthy that while advising the United States and Russia to downgrade their nuclear potentials to its level, China does not say 
what exactly this level is. One of the rare official statements (if not the sole one) on that score was the Chinese Foreign Ministry's statement, published on April 27, 2004, that China's nuclear arsenal was the smallest of all (Fact Sheet China, 2004). Even in that case the Chinese Foreign Ministry did not specify if it was referring to the quintet of the UN Security Council's permanent members. If so, China's nuclear arsenal, according to official statistics, consisted of no more than 190 warheads (Britain's level that year). Such (understated according to most analysts) estimates, have also been mentioned by a number of experts. For example, Harvard researcher Hui Zhang says China in 2011 had 166 nuclear warheads. There are other, higher estimates. For instance, Professor Phillip Karber of Georgetown University believes that China has 3,000 warheads at its disposal (Karber, 2011), while many other researchers call this in question.

The estimate offered by H. Kristensen and M. Korda of the Federation of American Scientists, who issue annual world surveys of nuclear arms potentials, is shared by most researchers and draws no objections from political circles in various countries, including the United States. According to their calculations as of April 2020, the United States had 3,800 deployed and non-deployed nuclear warheads, and Russia, 4,312 warheads. As for China, the same survey says it has 320 non-deployed nuclear warheads (Kristensen and Korda, 2020).

While underscoring the importance of nuclear arms cuts by the United States and Russia to China's level, Beijing does not specify if this idea applies only to strategic or all nuclear weapons. In the former case, if China's approach is to be accepted, Russia and the United States would have to slash their nuclear arsenals by 65\%-75\% (from 1,550 deployed nuclear warheads in compliance with the rules of the still effective New START). But if the total number of nuclear warheads on either side is to be counted, each country's nuclear potential would shrink by no less than $90 \%$. Only after this will China be prepared to consider in earnest its participation in nuclear arms control talks.

The United States and Russia can hardly find this suitable. At the same time, these countries have not yet officially formulated their specific approaches to and basic provisions of hypothetical trilateral 
talks and a future agreement on this issue. For the time being, these issues are in the focus of experts' attention in a number of countries, and they have over the past few years offered a variety of possible formats and parameters of a future "multilateral" treaty. In most cases, experts delve into certain aspects of a future agreement that might be attractive to China. Very few think of what China might lose the moment it enters into nuclear arms control talks or what militarypolitical consequences might follow if China eventually changed its mind regarding participation in such negotiations.

In my opinion, China's demand for achieving the "comparability" of nuclear potentials as a precondition for beginning a trilateral dialogue stems precisely from its evaluation of the consequences of its participation in the negotiations. This stance is neither far-fetched nor propagandistic, contrary to what some experts and politicians claim, but rests upon major political, military and strategic cornerstones. Disregard for China's arguments actually reduces to nothing all efforts, above all those taken by Washington, to engage Beijing in nuclear arms talks.

As far as the United States is concerned, the motives behind its attempts to persuade China to join nuclear arms talks are not quite clear. There may be several possible considerations that the United States is guided by in its policy on the issue. One is that Washington may be looking for a way to obtain necessary information about the current state of China's nuclear potential and plans for its development in the future in order to be able to adjust its own modernization programs accordingly. Another explanation is that the United States may be reluctant to go ahead with the nuclear disarmament policy and hopes to use China's unequivocal refusal to participate in negotiations as a chance to blame it for the disruption of this process and for dismantling the nuclear arms control system as such. I believe both explanations may be true, but their analysis lies beyond the scope of this article.

\section{OPTIONS OF ENGAGING CHINA IN NUCLEAR ARMS CONTROL TALKS}

The United States has not formulated in detail its official stance on engaging China in negotiations yet. Disarmament experts consider 
a number of options that may be proposed in principle. These options may be grouped into three main categories. The first one is putting pressure on China with the aim of making it change its mind regarding arms control. The second one is the search for proposals China may find lucrative enough, which the Chinese leadership might agree to study in earnest. And the third one is a combination of these two approaches.

As far as pressure on China is concerned, the United States is already exerting it along several lines. For one, China is criticized for the condition and development prospects of its nuclear arsenal. Specifically, it is blamed for being the only nuclear power in the Permanent Big Five that has not reduced its nuclear potential. Moreover, as follows from a statement made in May 2019 by Robert Ashley, Director of the Defense Intelligence Agency, "over the next decade, China is likely to at least double the size of its nuclear stockpile in the course of implementing the most rapid expansion and diversification of its nuclear arsenal in China's history" (Adamczyk, 2019). Both officials and many experts have been quoting this postulate as an established fact requiring no proof.

China is also accused of the lack of transparency, that is, refusal to disclose the size and structure of its nuclear forces, programs for their upgrade, and other nuclear policy aspects. The U.S. leadership argues that this state of affairs by no means promotes strategic stability and international security. Some experts believe that China's involvement in negotiations would help avoid some adverse effects, for example, another nuclear arms race under a Cold War scenario (Zhao, 2020). Rose Gottemoeller, U.S. Undersecretary of State for Arms Control and International Security in the Barack Obama administration, believes it may be possible to "make a case for the Chinese to come to the table early on intermediate-range constraints of ground-launched missiles, because they are staring at the possibility of a deployment of very capable U.S. missiles of this kind" (Mehta, 2020).

Apparently, the United States had counted on Russia's support in such matters, especially as the Russian leadership said more than once that the New START, signed in 2010, was to become the last bilateral nuclear arms reduction treaty and time was ripe for other nuclear states 
to join the nuclear disarmament process. However, in late 2019 Russia made a U-turn in its stance on China's participation in negotiations. Speaking at a conference entitled "Foreign Policy Priorities of the Russian Federation in Arms Control and Nonproliferation in the Context of Changes in the Global Security Architecture," held on November 8, 2019 in Moscow, Russian Foreign Minister Sergei Lavrov said that Russia respected China's position concerning its refusal to participate in the talks. Moreover, he stated that declaring China's consent to participate in the negotiating process as a precondition looked "openly provocative." Thus Russia made it clear that it had no intention of putting pressure on China regarding the issue, but at the same time it would have nothing against the Chinese leadership eventually making a decision to join the United States and Russia in nuclear disarmament talks. Russia is unlikely to alter its position even under pressure from the United States, which has long harbored plans for using the prolongation of the New START as a factor for getting China involved in the talks in some way, or even securing its consent to become a signatory to the treaty. Specifically, the U.S. president's National Security Advisor Robert O'Brian made an unequivocal statement on that score (Riechmann, 2020). Also, in May 2020, the United States came up with an ultimatum that it would not extend the New START until China agreed to participate in it. Moreover, the newly appointed special U.S. presidential representative for arms control, Marshall Billingslea, actually demanded that Russia "bring the Chinese to the negotiating table."

The United States may exert (or is already exerting) pressure on China "indirectly," for example by using such levers as the U.S.Chinese trade war and China's alleged "responsibility" for the spread of the coronavirus (which the United States regards as proven). Such pressures may be largely exerted covertly.

Some military and political experts believe that it is worth exploring compromise options of China's participation in nuclear arms control. Such options may accommodate the interests of all partakers and match the specific structure and quantitative parameters of weapons subject to control. Establishing transparency in the given sphere would 
be one of the "simple" ways of involving China in the strategic dialogue. In other words, such transparency would imply mutual disclosure of information about the number of missiles and deployed warheads, their basic parameters, including range, and also specific locations and deployment sites (Tosaki, 2019). It must be noted that this seemingly "least painful" and easy-to-accomplish solution for making China join the international arms control dialogue is in fact least acceptable to it.

The long list of other proposals includes various options of a "mixed" approach to the control of missile systems. For instance, reaching an agreement on a common ceiling for intermediate-range ground-based and air-launched missiles or a similar restriction on any strategic missiles regardless of the type of deployment (ground, sea, or air launched), as well as the intermediate-range missiles of three nuclear powers-China, the United States, and Russia. The proponents of this approach believe that this may provide an approximately equitable basis for talks among the aforesaid states (Zhao, 2020).

All of the aforementioned recommendations-and a number of other ideas-for plugging China into bilateral or multilateral nuclear arms control talks are based on the past experience of negotiations on the issue. In the meantime, the specifics of China's nuclear policy are left unnoticed or intentionally ignored. It is generally believed that inviting China to participate in negotiations is tantamount to official recognition of its status as a great power responsible, like the United States and Russia, not only for its own security but also for global security. This recognition is often considered a reason enough to expect China to consent to participate in such negotiations and the main problem is seen in the formulation of concrete proposals for discussion. In the meantime, such an approach looks erroneous.

\section{THE FUNDAMENTAL PRINCIPLES OF CHINA'S NUCLEAR POLICY}

China's policy concerning nuclear arms and their role in maintaining national security has remained unchanged for more than 55 years, starting from its accession to the "nuclear club" in 1964. Central to that policy is China's pledge not to be the first to use nuclear weapons or threaten to use them against non-nuclear countries and countries in 
nuclear free zones. It is believed that Mao Zedong made that decision personally in 1964 (Fravel, 2019).

In accordance with this pledge, China, as it reiterates, maintains its nuclear deterrence weapons at a required minimum by declaring its readiness for retaliation against an aggressor in the event of a hypothetical nuclear attack. China vows it does not participate in a nuclear arms race against any country. These provisions have remained unchanged for many years and can be found in many Chinese fundamental military and strategic planning documents, available from open sources (The State Council, 2019), and are repeatedly quoted by the Chinese mass media (Xinhuaneet.com., 2019).

In contrast to the classical nuclear deterrence formula China does not demonstrate its retaliatory strike capabilities; on the contrary, it conceals them for various reasons. Enhancing the survivability of retaliatory strike systems is one. Such "existential" means of deterrence enables the country possessing a relatively small nuclear potential to keep a potential aggressor in a state of strategic uncertainty as it cannot be certain that its first strike would "disarm" the defending opponent by eliminating all of its nuclear weapons with a surprise counterforce strike.

To confirm its adherence to the no-first use principle, China declares that it limits its nuclear potential to the "minimum" defense requirements, while all upgrade programs are geared mostly to ensuring the survivability and reliability of retaliatory strike systems. China's nuclear forces have become more survivable due to the creation and deployment of mobile ICBMs, and measures to shelter a considerable part of its nuclear potential, including mobile ICBMs and shorter-range missiles in a network of underground tunnels - the Underground Great Wall of China. Also, other means of hiding nuclear weapons are used, such as mock ICBM silos and shelters for nuclear submarines inside coastal rocks.

As the information about the condition, development prospects and size of China's nuclear potential remains scarce, its nuclear policy issues are in the focus of attention of many specialists and think tanks in the United States and other countries. Most of them (but far from 
all) believe that China's declared policy of no-first-use of nuclear weapons and estimates of its nuclear potential (around 300 warheads) agree with reality (Pifer, 2019). But other researchers maintain that under certain circumstances China may revise its attitude to the nofirst-use principle and abandon the minimum deterrence concept in favor of gaining opportunities for conducting limited nuclear war. Such conclusions are made on the basis of data showing the growth of qualitative parameters of China's nuclear forces-greater accuracy of nuclear warheads, the deployment of MIRVs on ICBMs, forecasts for a considerable increase in the overall number of nuclear weapons at the country's disposal, etc. (Giacomdetti, 2014; Yoshihara and Bianchi, 2019; Schneider, 2019).

It should be acknowledged that the lack of official information about the condition and development prospects of China's nuclear arsenal and implementation of programs in the strategic field (creation of a heavy ICBM, research and development of a missile attack warning system, deployment of a missile defense, and others) afford ground for a variety of speculations over China's compliance with the professed principles regarding nuclear weapons. In the meantime, this by no means contradicts the fundamental principle of China's nuclear policy-no-first-use of nuclear weapons-which will remain unchanged in the foreseeable future. Even if one assumes that China does participate in the nuclear arms race (which is also a subject of speculations), it is by no means its instigator.

Certain changes are possible, though. China may acquire real capabilities for a limited response to a limited nuclear attack. In other words, the country's military-political leadership, empowered to make a decision to use nuclear weapons, will acquire extra opportunities and options for retaliation other than a massive nuclear strike against the enemy's major unprotected targets, such as cities and industrial centers. At the same time there is no reason to say that the improvement of parameters of China's strategic nuclear forces increases the risk of a first counterforce strike against a would-be aggressor just because the nuclear potentials of China and the two leading nuclear powers are incomparable. In this case size does matter. 


\section{EFFECTS OF ARMS CONTROL ON CHINA'S NUCLEAR STRATEGY AND POLICY}

Should China agree to participate in negotiations or draft an agreement on control of its nuclear weapons, its nuclear strategy and policy will most likely undergo the most serious changes. And these changes, in the author's opinion, may be far from positive. They will result not from possible restrictions imposed on China's nuclear forces or disadvantageous terms of a future treaty forced upon China, but the very fact of concluding such an international treaty.

A close look at Soviet-U.S. and Russian-U.S. nuclear arms control agreements reveals how the parties' approaches to solving the problems of national security and strengthening strategic stability have been changing. At early stages the two sides managed to come to terms regarding the overall number of ground-based launchers of strategic ballistic missiles, SLBM-capable submarines and SLBM launchers. Later, the class of strategic weapons was expanded to incorporate heavy bombers armed with long-range cruise missiles and gravity nuclear bombs. Some types of nuclear weapons, for instance, strategic air-launched ballistic missiles were banned. Next, there followed restrictions on nuclear warheads deployed on delivery vehicles and then their reductions. A total ban was applied to groundbased intermediate- and shorter-range cruise missiles. An attempt was made to outlaw ICBMs with multiple warheads. Each clause of the concluded treaties was scrutinized by the expert community and drew worldwide interest.

In addition, efforts were made to develop a mechanism to verify compliance with the assumed commitments. The first Soviet-U.S. agreements SALT-1 (1972) and SALT-2 (1979) assigned the control function to "national technical means of verification"-intelligence satellites. The contracting parties pledged to refrain from creating impediments to their operation. Also, the signatories undertook "not to use deliberate concealment measures which impede verification by national technical means of compliance." In the next agreementsthe INF Treaty (of 1987) and, particularly, START-1 (1991)-a comprehensive system of control and verification was developed and 
adopted. It envisaged exchanges of data (including the geographical coordinates of each ICBM silo) and various notifications and on-site inspections, which made it totally impossible to conceal even the slightest violations of these agreements. This system of verification functions within the framework of the still effective Russian-U.S. New START, concluded in 2010.

It is hard to imagine a hypothetical agreement with China not including compliance verification procedures. And it is very unlikely that the system of verification in such an agreement will be "soft," as was the case with the one established under the earlier SALT-1 and SALT-2 treaties. On the contrary, as follows from statements by U.S. officials, the United States is determined to pay the closest attention to the verification and control of compliance with all future agreements. U.S. Acting Under Secretary of State for Arms Control and International Security Christopher Ford has made an explicit statement on this score.

Even if such an agreement does not impose any obligations on China, requiring reduction of its nuclear potential, Beijing will be expected to provide exhaustive information about its nuclear weapons and deployment sites. Also, China will have to give up measures to conceal its nuclear forces, change the locations of mobile missile systems and allow foreign inspectors to visit classified facilities (including the Underground Great Wall of China) in order to confirm that the provided information is correct and proper action has been taken under assumed commitments. Besides, China will have to notify other signatories of the commissioning of new nuclear weapons and withdrawal from operational duty or elimination of older systems, the redeployment of weapons, etc. All these measures will make it possible to keep under full control China's nuclear potential and nuclear arms delivery vehicles.

These measures, understandable from the standpoint of an arms control treaty, may have truly disastrous effects on China's entire official nuclear policy. Information disclosure and control measures would make China's nuclear arsenal totally vulnerable to a first nuclear strike and-partially-to a non-nuclear strike. A potential aggressor, possessing a considerable advantage in nuclear weapons and 
full information about the deployment sites, will have a guaranteed capability to destroy the adversary's entire nuclear potential. Theoretically, it would spend far more nuclear weapons than the victim of the aggression (in this particular case, China) would lose, but still retain an enormous attack potential. In a situation like this, there will be no weapons available to deliver a retaliatory strike. All this will mean that China's declared no-first-use policy will lose credibility. In other words, it will turn into a propaganda slogan, with no real resources to rely on to implement this policy in practice.

Apparently, it is precisely these considerations that are behind China's refusal to participate in nuclear arms control talks, and they will remain in place at least until the strategic situation in this field undergoes fundamental change. One of the most important conditions for China to enter into such negotiations (it says so openly) is further reduction of nuclear arsenals by Russia and the United States to levels comparable with China's potential. As it has already been stated, this condition, described as a political one, has fundamental strategic, military and technical grounds.

\section{LIKELY CONSEQUENCES OF CHINA'S PARTICIPATION IN A NUCLEAR ARMS CONTROL TREATY}

As has been said above, China's consent to enter into nuclear arms control negotiations and conclusion of a corresponding agreement will be unlikely in the foreseeable future. Nevertheless, it is worth pondering on what decisions in the military and political field the Chinese leadership may adopt if it has to give in to U.S. pressure. One of the most important decisions is, to my mind, the possibility of China remaining committed to the no-first-use principle.

Currently, this principle is ensured not so much by the quantitative parameters of China's nuclear arsenal but as its stealthy deployment, concealment measures, and refusal to provide relevant information. In order to retain a retaliatory strike potential in a situation where the information about the deployment sites of China's nuclear forces has been disclosed while the amount of nuclear arms available remains considerably inferior to those of the "partner" or "partners," China will 
have to exert major efforts to ensure the invulnerability of at least some of them. Doing this will be impossible without a major buildup of the nuclear potential, above all, of the least vulnerable strategic systems (mobile ICBMs and SLBMs). All of this will require considerable expenses and time. Even if the work on a new treaty takes two or three, or even five years, one can hardly expect any considerable changes in the quantitative and qualitative structure of China's nuclear forces by the moment this work is finalized.

The problem of strategic nuclear forces' vulnerability may theoretically be resolved (at least to a certain extent) by developing and deploying missile defenses around deployment sites. But this would entail heavy spending, too. Also, such a program can hardly be implemented within tight deadlines. The problem of greater vulnerability of China's strategic nuclear forces can also be resolved by adopting the "launch-under-attack" concept or "launch on warning" concept. Their adoption might be considered, although with great reservations, to conform to the no-first-use principle, but in this case it will be essential to build a warning system based on early warning satellites and radars. However, still there will be no guarantees that such a system will be able to issue a timely notification to the military and political leadership of a missile attack against China, if such a strike is carried out with U.S. SLBMs having short flight-in time and counterforce capability. Under such a scenario China's strategic forces will have to remain on high alert all the time. This means that China will be forced to give up keeping missile warheads in store separately and to deploy them on strategic delivery vehicles, thus demonstrating its readiness for instant retaliation in case of an attack warning.

The above arguments prompt the conclusion that China, if it agrees to the drafting and signing of a nuclear arms control treaty, will certainly have to depart from the principle of no-first-use of nuclear weapons, with all the ensuing negative consequences. This may also trigger an enhanced arms race and induce China to adopt more aggressive nuclear arms concepts.

It is nakedly clear that China finds it far easier to refuse to hold nuclear arms control talks than address the adverse military and 
strategic effects its participation in such an international agreement is bound to entail. In this situation the United States should give more thought to its policy of engaging China in nuclear arms control talks and focus on Russian-U.S. strategic relations, including the prolongation of the New START without any linkages and preconditions.

As far as Russia is concerned, its current policy of avoiding pressure on China to make it engage in nuclear arms talks looks reasonable. From the political standpoint-alongside with other considerations-a trilateral agreement would mean that Russia officially regards China, albeit formally, as a "partner" (if not a "potential adversary"), just as the United States, and that strategic relations among such parties are based on the concept of nuclear deterrence, the balance of nuclear forces, and their capabilities to deliver first and retaliatory strikes. Incidentally, China's participation would have the same implications for Russia. Lending this dimension to bilateral relations hardly meets the interests of the two countries.

\section{References}

Adamczyk, E., 2019. "China Will Double Its Nuclear Warheads in Next 10 Years," DIA Chief Says. Defense News, 31 May [online]. Available at: $<$ https://www.upi. com/Defense-News/2019/05/31/China-will-double-its-nuclear-warheads-innext-10-years-DIA-chief-says/1621559319133/> [Accessed 11 May 2020].

ECNC, 2020. "China Will Not Join So-Called China-U.S.-Russia Arms Control Negotiations”. ECNC.cn [online]. Available at: <http://www.ecns.cn/news/ politics/2020-03-06/detail-ifzuhesu4122041.shtml> [Accessed 20 March 2020].

Fact Sheet China, 2004. Nuclear Disarmament and Reduction of. Ministry of Foreign Affairs of the People's Republic of China, Fact Sheet China, 27 April.

Ford, C., 2020. US Priorities for "Next Generation Arms Control”. US Department of State. Arms Control and International Security Papers, 1(1), o6 April, p. 4.

Fravel, M., 2019. China Has Not (Yet) Changed Its Position on Nuclear Weapons. The Diplomat, 22 April [online]. Available at: <https://thediplomat. com/2013/04/china-has-not-yet-changed-its-position-on-nuclear-weapons/> [Accessed 5 May 2020]. 
Gertz, B., 2020. Envoy Says China Is Key to New Arms Deal with Russia. The Washington Times, 7 May [online]. Available at: $<\mathrm{https}: / / \mathrm{m}$.washingtontimes. com/news $/ 2020 /$ may/7/marshall-billingslea-says-new-start-fate-hangs-chi/> [Accessed May 10, 2020].

Giacometti, N., 2014. For Half a Century, China's Nuclear Strategy Has Been Surprisingly Consistent. Will It Remain So? The Diplomat, 16 October [online]. Available at: $<$ https://thediplomat.com/2014/10/could-chinas-nuclear-strategyevolve/> [Accessed 5 May 2020]

Karber, Ph. A., 2011. Strategic Implications of China’s Underground Great Wall. Federation of American Scientists, 11 September [pdf]. Available at: $<$ https://fas. org/nuke/guide/china/Karber_UndergroundFacilities-Full_2011_reduced.pdf> [Accessed June 22, 2020]

Kristensen, H. and Korda, M., 2020. Status of World Nuclear Forces. Federation of American Scientists [online]. Available at: <https://fas.org/issues/nuclearweapons/status-world-nuclear-forces/> [Accessed 10 August 2020].

Mehta, A., 2020. Arms Control Decisions by Trump Administration Could Be 'Imminent.' Will China Be Involved? Defense News, 26 February, [online]. Available at: <https://www.defensenews.com/pentagon/2020/02/26/armscontrol-decisions-by-trump-administration-could-be-imminent-will-chinabe-involved/> [Accessed 11 May 2020].

MFA RF, 2019. Foreign Minister Sergey Lavrov's remarks at the Moscow Nonproliferation Conference "Foreign Policy Priorities of the Russian Federation in Arms Control and Nonproliferation in the Context of Changes in the Global Security Architecture". 8 November [online]. Available at: $<$ https://www.mid.ru/ foreign_policy/news/-/asset_publisher/cKNonkJE02Bw/content/id/3891674> [Accessed 12 April 2020].

Ministry of Foreign Affairs of the People's Republic of China, 2019. Foreign Ministry Spokesperson Geng Shuang's Regular Press Conference on May 6, 2019. [online]. Available at: <https://www.fmprc.gov.cn/mfa_eng/xwfw_665399/ s2510_665401/2511_665403/t1661163.shtml> [Accessed 11 May 2020].

Pifer, S., 2019. Order from Chaos. Russia’s Shifting Views of Multilateral Nuclear Arms Control with China. Brookings, 19 February [online]. Available at: <https://www.brookings.edu/blog/order-from-chaos/2020/02/19/russiasshifting-views-of-multilateral-nuclear-arms-control-with-china/ $>$ [Accessed June 22, 2020]. 
Reuters, 2020. Reuters World News official website, 7 May. Available at: <https:// www.reuters.com/article/us-usa-trump-russia/trump-stresses-desire-for-armscontrol-with-russia-china-in-putin-call-idUSKBN22J2GT>. [Accessed 11 May 2020].

Riechmann, D., 2020. Trump Still Hoping for US-Russia-China Nuclear Arms Pact. The Star, 14 February [online]. Available at: <https://www.thestar.com/ news/world/us/2020/02/14/trump-still-hoping-for-us-russia-china-nucleararms-pact.html> [Accessed 12 April 2020].

Schneider, M. B., 2019. Nuclear Weapons in Chinese Military Strategy. National Institute for Public Policy. Information Series. Issue No. 441, 3 May 3. [online]. Available at: <https://www.nipp.org/wp-content/uploads/2019/05/IS-441.pdf> [Accessed 11 May 2020].

Tosaki, H., 2019. Nuclear Arms Control in a Post-INF Treaty Period: A Chance to Engage China? The Japan Institute of International Affairs. JIIA Strategic Comments, No. 9, March [online]. Available at: <https://www2.jiia.or.jp/en/ article_page.php?id=18> [Accessed 5 May 2010].

The State Council, 2019. Information Office of the People's Republic of China, 2019. China's National Defense in the New Era, July. Beijing: Foreign Languages Press Co. Ltd., p. 9.

Xinhuanet.com, 2019. China Pursues Nuclear Strategy of Self-Defense: White Paper. Xinhua, 24 July [online]. Available at: <http://www.xinhuanet.com/ english/2019-07/24/c_138253330.htm> [Accessed 5 May 2020].

Yoshihara Toshi and Bianchi, J., 2019. Chinese Nuclear Weapons Strategy Technical-Military Developments and Perceptions of Credibility. Real Clear Defense, July 17. <https://www.realcleardefense.com/articles/2019/07/17/ chinese_nuclear_weapons_strategyleaning_towards_a_more_proactive_ posture_part_ii_external_drivers_of_potential_changetechnical-military_ developments_and_perceptions_of_credibility.html> [Accessed 5 May 2020].

Zhang Hui, 2011. China’s Nuclear Weapons Modernization: Intentions, Drivers, and Trends. Project on Managing the Atom, Kennedy School of Government, Harvard University, [online]. Available at: $<$ http://belfercenter.hks.harvard.edu/ files/ChinaNuclearModernization-hzhang.pdf> [Accessed June 22, 2020].

Zhao, T., 2020. Opportunities for Nuclear Arms Control Engagement with China. Arms Control Today, January/February [online]. Available at: <https:// www.armscontrol.org/act/2020-01/features/opportunities-nuclear-armscontrol-engagement-china\#bio> [Accessed 5 May, 2020]. 